\title{
DISINFECTION OF WATER FOR AQUACULTURE
}

\author{
HISAE KASAI, ${ }^{1}$ MAMORU YOSHIMIZU ${ }^{1}$ AND YOSHIO EZURA ${ }^{1}$ \\ Laboratory of Biochemistry and Biotechnology, Division of Marine Bioscience, Graduate School of Fisheries \\ Science, Hokkaido University, Minato 3-1-1, Hakodate, Hokkaido 041-8611, Japan.
}

SUMMARY: Disinfection of water for aquaculture is critical for preventing the introduction and spread of infectious disease. A pathogen-free water source is essential for success in aquaculture. Typical treatment systems make use of high efficiency sand filters to clarify the water before treatment with ultraviolet (UV) light or ozonization. Fish pathogens are divided into two groups based on their sensitivity to UV and total residual oxidants (TROs) produced by ozonization of seawater. Hypochlorite produced by electrolysis of seawater (salt water) showed bactericidal and viricidal effects. This method can easily treat large volumes of water, and is suitable for disinfecting wastewater before discharging.

\section{KEY WORDS: disinfection, aquaculture, fish pathogen, UV, ozone, oxidant, electrolization}

\section{INTRODUCTION}

Water supplies for seed production and aquaculture often provide an efficient means for the introduction and spread of infectious diseases. A pathogen-free water source is essential for success in aquaculture. Surface waters commonly used in aquaculture come from coastal waters or rivers and may contain some fish pathogens and such open water supplies should not be used without treatment. Disinfection of wastewater before discharging is necessary to avoid the pathogen contamination in the environment. In this study, we examine the cidal effect of ultraviolet (UV), oxidant produced by ozonization of seawater and hypochlorite produced by electrolization of seawater. Additionally the disinfectant effects of the three methods for a hatchery water supply and

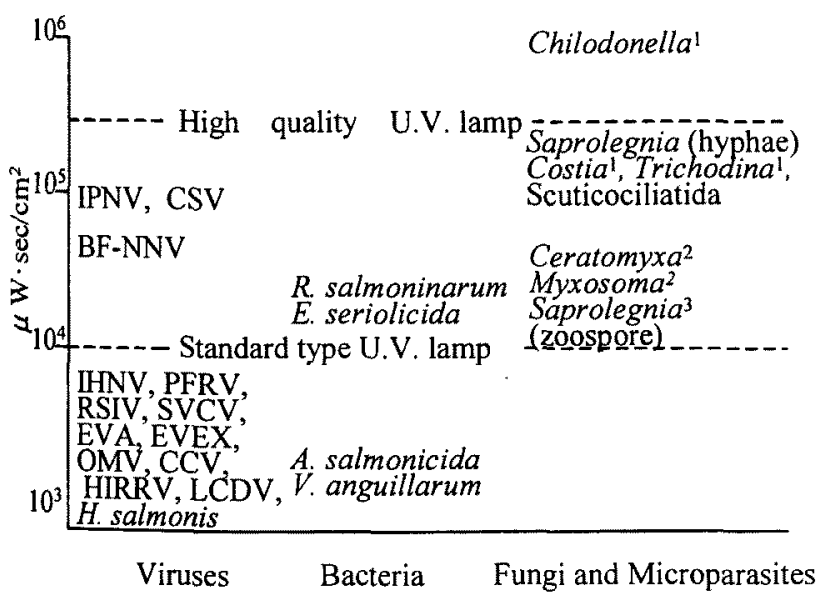

Fig. 1. U.V. susceptibility of fish pathogens.

${ }^{1}$ Vlasenko, M. I. (1969) ${ }^{2}$ Hoffman, G. L. (1974)

${ }^{3}$ Normandeau, D. A. (1968) wastewater were compared and the survival rate of cultured fish that were reared using water treated with these methods was assessed.

UV susceptibility of fish pathogens and the effects of UV treatment on hatchery water

The disinfectant effects of UV irradiation were examined on cell suspensions of 4 species of fish pathogenic bacteria and Escherichia coli, using a punched agar medium disk covered with 10 strains of aquatic fungi and 14 strains of cell free fish pathogenic viruses. Of the viable bacterial cells of Gram negative bacteria and Gram positive bacteria, $99.9 \%$ or more were killed by UV irradiation at the dose of $4.0 \times 10^{3}$ and $2.0 \times 10^{4} \mu \mathrm{W} \cdot \mathrm{sec} / \mathrm{cm}^{2}$, respectively. ${ }^{4)}$ The hyphae of aquatic fungi showed relatively lower susceptibility to UV irradiation, levels that inhibited the growth of hyphae were $1.5 \times 10^{5}$ to $2.5 \times 10^{5} \mu \mathrm{W} \cdot \mathrm{sec} / \mathrm{cm}^{2}$. ${ }^{5}$ Six fish rhabdoviruses, three fish herpesviruses and two fish iridovirus were found to be sensitive to UV irradiation. The dose that resulted in a $99 \%$ or more infectivity decrease $\left(\mathrm{ID}_{99}\right)$ was observed at the dose of $1.0 \times 10^{3}$ to $3.0 \times 10^{3}$ $\mu \mathrm{W} \cdot \mathrm{sec} / \mathrm{cm}^{2}$. Susceptibility of two birnaviruses, a fish reovirus and a fish nodavirus was found to be low, $\mathrm{ID}_{99}$ measured $1.5 \times 10^{5}$ to $2.5 \times 10^{5} \mu \mathrm{W} \cdot \mathrm{sec} / \mathrm{cm}^{2}$ (Fig. 1). ${ }^{6)}$

The infectivity of infectious hematopoietic necrosis virus (IHNV), in virus-contaminated river water and pond water, as measured by the molecular filtration method was 0.56 and $5.6 \mathrm{TCID}_{50} / l$, respectively. UV treatment of river water with $10^{4} \mu \mathrm{W} \cdot \mathrm{sec} / \mathrm{cm}^{2} \mathrm{UV}$ dose prevented an IHN outbreak. ${ }^{7)}$ Furthermore, UV treatment of the hatchery water supply also decreased the viable bacterial counts and fungal infection rates of salmonid eggs. ${ }^{8)}$ 
Table 1. Effect of total residual oxidants (TROs) concentrations produced by ozonization of seawater on infectivities of fish pathogens

\begin{tabular}{|c|c|c|c|c|c|}
\hline \multicolumn{2}{|l|}{ Fish pathogens } & $\begin{array}{c}\text { TROs } \\
\text { concentration } \\
(\mathrm{mg} / \mathrm{l})\end{array}$ & $\begin{array}{c}\text { Treatment } \\
\text { time } \\
(\mathrm{sec}) \\
\end{array}$ & $\begin{array}{l}\text { Reduction } \\
\text { rate } \\
(\%) \\
\end{array}$ & $\begin{array}{c}\text { Initial number } \\
\text { (Log.) }\end{array}$ \\
\hline \multicolumn{2}{|c|}{ Yellowtail ascites virus (YAV) } & 0.5 & 60 & $>99$ & $4.3^{1}$ \\
\hline \multicolumn{2}{|c|}{ hirame rhabdovirus (HIRRV) } & 0.5 & 15 & $>99$ & $5.6^{\mathrm{l}}$ \\
\hline \multicolumn{2}{|c|}{ Infectious pancreatic necrosis virus (IPNV) } & 0.5 & 60 & $>99$ & $4.1^{!}$ \\
\hline \multicolumn{2}{|c|}{ Infectious haematopoietic necrosis virus (IHNV) } & 0.5 & 15 & $>99$ & $4.1^{1}$ \\
\hline \multicolumn{2}{|c|}{ Oncorhynchus masou virus (OMV) } & 0.5 & 15 & $>99$ & $3.1^{i}$ \\
\hline \multicolumn{2}{|c|}{ Chum salmon virus (CSV) } & 0.5 & 60 & $>99$ & $4.1^{1}$ \\
\hline Vibrio anguillarum & NCMB6 & 0.5 & 15 & $>99.9$ & $5.6^{2}$ \\
\hline Enterococcus seriolicida & 538 & 0.5 & 15 & $>99.9$ & $5.8^{2}$ \\
\hline Aeromonas salmonicida & ATCC 14174 & 0.5 & 15 & $>99.9$ & $5.1^{2}$ \\
\hline Aeromonas hydrophila & IAM 1018 & 0.5 & 15 & $>99.9$ & $4.6^{2}$ \\
\hline Scuticociliatida & BR-9001 & 0.8 & 30 & $>99.9$ & $5.5^{3}$ \\
\hline
\end{tabular}

${ }^{1}$ Initial viral infectivity $\left(\mathrm{TCID}_{50} / \mathrm{m} l\right) .{ }^{2}$ Initial viable bacterial number $(\mathrm{CFU} / \mathrm{m} l) .{ }^{3}$ Initial viable number .

Disinf ectant effect of oxidant produced by ozonization of sea water on fish pathogens

Treatment of natural seawater with ozone produced oxidant that showed a disinfectant effect. Total residual oxidant (TROs) produced in seawater were stable for $1 \mathrm{~h}$ or more. Disinfectant effect of TROs against fish pathogenic organisms was observed at a dose of $0.5 \mathrm{mg} / l$ for 15 to $30 \mathrm{~s}$ or $0.1 \mathrm{mg} / l$ for $60 \mathrm{~s}$,
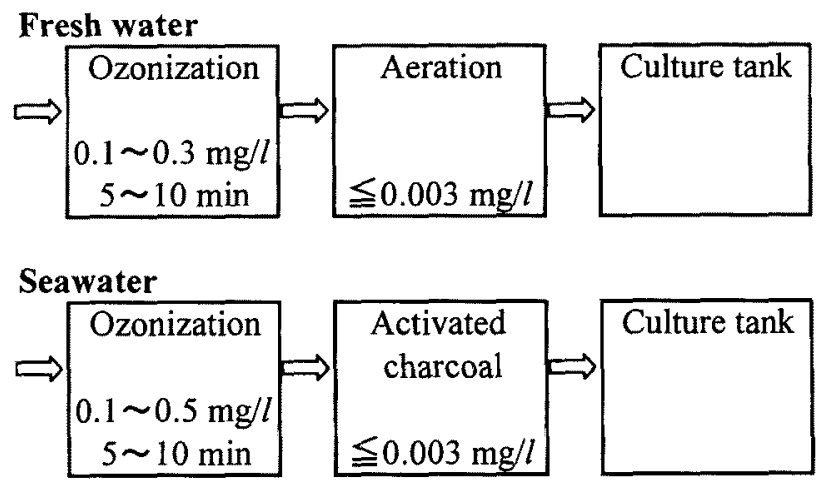

Fig. 2. Ozonization of water for aquaculture. and killed more than $99.9 \%$ of bacterial cells of Vibrio anguillarum, Enterococcus serioricida, Aeromonas salmonicida, $A$. hydrophila and $E$. coli, and inactivated $99 \%$ or more of IHNV, hirame rhabdovirus (HIRRV) and Oncorhynchus masou virus (OMV). To inactivate or kill more than $99 \%$ of yellowtail ascites virus (YAV), infectious pancreatic necrosis virus (IPNV), chum salmon virus (CSV), and a Scuticociliatida (ciliata), higher doses of 0.5 to 1.0 $\mathrm{mg} / \mathrm{l}$ for $1 \mathrm{~min}$ were required (Table 1$)^{9,10)}$

TROs showed toxicity for fish. Barfin flounder Verasper moseri and herring Clupea pallasii died after 16 and $2 \mathrm{~h}$ exposure to TROs of 0.1 and $0.5 \mathrm{mg} / \mathrm{l}$, respectively. However, Japanese flounder could be cultured in ozonized seawater after the TRO were removed by charcoal (Fig.2), resulting in survival rates similar to fish cultured in UV treated or non-treated seawater. ${ }^{11)}$

\section{Disinfectant effects of electrolyzed salt water on fish pathogenic bacteria and viruses}

The bactericidal and viricidal effects of hypochlorite produced by electrolysis of salt water were examined against pathogenic bacteria and viruses of fish.

Table 2. The chlorine concentration produced by electrolysis of salt water and treatment time required to reduce the viability of bacteria and the infectivity of viruses by $99.9 \%$

\begin{tabular}{lccccc}
\hline \hline Pathogens & $\begin{array}{c}\text { Chlorine } \\
\text { concentration } \\
(\mathrm{mg} / \mathrm{l})\end{array}$ & $\begin{array}{c}\text { Treatment } \\
\text { time } \\
(\mathrm{min})\end{array}$ & $\begin{array}{c}\text { Initial } \\
\text { number } \\
(\mathrm{Log} .)\end{array}$ & $\begin{array}{c}\text { Reduction } \\
\text { rate } \\
(\%)\end{array}$ \\
\hline Vibrio anguillarum & NCMB6 & 0.07 & 1 & $6.7^{1}$ & $>99.99$ \\
Aeromonas salmonicidc ATCC 14174 & 0.06 & 1 & $6.6^{1}$ & 99.96 \\
$\begin{array}{l}\text { Escherichia coli } \\
\text { Yellowtail ascites virus (YAV) }\end{array}$ & 0.14 & 1 & $6.6^{1}$ & 99.98 \\
\hline hirame rhabdovirus (HIRRV) & 0.45 & 1 & $4.5^{2}$ & 99.92 \\
\hline
\end{tabular}

${ }^{1}$ Initial viable bacterial number $(\mathrm{CFU} / \mathrm{m} l) .{ }^{2}$ Initial viral infectivity $\left(\mathrm{TCID}_{50} / \mathrm{m} l\right)$. 
Table 3. Effects of U.V. irradiation, ozonization and electrolyzation on the viability of bacteria in hatchery waste-seawater

\begin{tabular}{lcccc}
\hline \hline Methods & $\begin{array}{c}\text { Flow rate } \\
\left(\mathrm{m}^{3} / \mathrm{h}\right)\end{array}$ & Treatment & $\begin{array}{c}\text { Viable } \\
\text { counts } \\
(\mathrm{CFU} / \mathrm{m} l)\end{array}$ & $\begin{array}{c}\text { Reduction } \\
\text { rate } \\
(\%)\end{array}$ \\
\hline Non-treated & 2.0 & - & $4.7 \times 10^{4}$ & - \\
\hline U.V. irradiation & 2.0 & $1.0 \times 10^{5} \mu \mathrm{W} \cdot \mathrm{sec} / \mathrm{cm}^{2}$ & $1.3 \times 10^{0}$ & 99.99 \\
Ozonization & 2.0 & TROs $0.5 \mathrm{mg} / l, 1 \mathrm{~min}$ & $3.0 \times 10^{\circ}$ & 99.99 \\
Electrolization & 2.0 & Chlorine $0.6 \mathrm{mg} / l, 1 \mathrm{~min}$ & $4.1 \times 10^{2}$ & 99.13 \\
\hline
\end{tabular}

Sodium chloride solutions, ranging from 0.5 to $3 \%$ were electrolyzed and the concentration of chlorine produced was measured. Similar concentrations of chlorine were produced when $1.0 \%$ or higher $\mathrm{NaCl}$ solution and seawater were electrolyzed. ${ }^{12)}$ A $3 \%$ solution of sodium chloride containing pathogenic bacteria or virus was electrolyzed and the organisms were exposed to chlorine. Greater than $99.9 \%$ of $V$. anguillarum and $A$. salmonicida cells were killed when the bacteria were exposed to $0.1 \mathrm{mg} / \mathrm{l}$ chlorine for $1 \mathrm{~min}$. YAV and HIRRV were $99.9 \%$ or greater inactivated after treatment with $0.45 \mathrm{mg} / l$ chlorine for 1 min (Table 2). ${ }^{13)}$

The bactericidal and viricidal effects of hypochlorite produced by electrolysis $\left(3.5 \mathrm{~m}^{3} / \mathrm{h}, 0.1 \mathrm{~A}\right)$ were greater than that of the chemical reagent. The purity of the sodium chloride used influenced the effects of production of hypochlorite. Sodium chloride obtained as a super grade chemical reagent was more effective than food-grade sodium chloride. However, a sufficient disinfectant effect was observed in electrolyzed seawater, a treatment which may have an application in aquaculture. To use electrolyzed seawater for culture, the chlorine has to be removed with charcoal because of its toxicity.

\section{Disinfection of wastewater}

The bactericidal effect of hypochlorite produced by a continuous flow electrolyzer on hatchery wastewater was investigated. The number of viable bacteria in the wastewater was reduced more than $99 \%$ when the water was treated with chlorine at a concentration of $0.6 \mathrm{mg} / \mathrm{l}$ for $1 \mathrm{~min}$, and over $99.9 \%$ of the bacteria cells were killed when treated with $1.28 \mathrm{mg} / \mathrm{l}$ for $1 \mathrm{~min}$ (Table 3). In another experiment, $2.0 \mathrm{~m}^{3} / \mathrm{min}$ of hatchery wastewater was electrolyzed and the produced hypochlorite that was mixed with the remaining, $16.5 \mathrm{~m}^{3} / \mathrm{min}$ wastewater. Viability of bacteria was reduced greater than $99 \%$ after treatment with $0.5 \mathrm{mg} / l$ of chlorite for $1 \mathrm{~min}$. The bactericidal effect of electrolysis was almost the same as that of ultraviolet irradiation $\left(1.0 \times 10^{5} \mu \mathrm{W} \cdot \mathrm{sec} / \mathrm{cm}^{2}\right)$ or ozonization (TROs $0.5 \mathrm{mg} / l, 1 \mathrm{~min}$ ) of seawater. Electrolization can be used to treat a large volume of wastewater compared with the ultraviolet irradiation or ozonization. $^{14}$

\section{Disifection of water for hatchery water supplies and survival rate of cultured fish}

The effects of the three disinfection methods on bacteria in the hatchery water supplies are shown in Table 4. All methods resulted in a reduction of 96.6 to $99.8 \%$ after the treatment. Survival rate of Japanese flounder Paralichthys olivaceus and barfin flounder

Table 4. Viability of bacteria in hatchery water supply after treatment using different disinfection methods

\begin{tabular}{|c|c|c|c|}
\hline Method & $\begin{array}{l}\text { Treatment } \\
\text { time (min) }\end{array}$ & $\begin{array}{l}\text { Viable counts } \\
(\mathrm{CFU} / \mathrm{m} l)\end{array}$ & $\begin{array}{l}\text { Reduction } \\
\text { rate }(\%)\end{array}$ \\
\hline Control & - & $2.2 \times 10^{2}$ & - \\
\hline U.V. irradiation & 1 & $7.3 \times 10^{0}$ & 96.6 \\
\hline Ozonization $^{2}$ & 5 & $5.0 \times 10^{-1}$ & 99.8 \\
\hline Electrolization $^{3}$ & 1 & $1.1 \times 10^{0}$ & 99.5 \\
\hline
\end{tabular}

Table 5. Survival rate of Japanese flounder cultured in U.V. irradiated, ozonized, electrolyzed or non-treated seaw

\begin{tabular}{|c|c|c|c|c|}
\hline Survival rate & U.V. irradiated ${ }^{\prime}$ & Ozonized $^{2}$ & Electrolyzed $^{3}$ & Non-treated \\
\hline Japanese flounder ${ }^{4}$ & 71.5 & 71.8 & NT & 67.4 \\
\hline Barfin flounder ${ }^{5}$ & NT & 34.3 & 32.6 & 25.7 \\
\hline \multicolumn{5}{|c|}{${ }^{1}$ U.V. dose: $1.0 \times 10^{4} \mu \mathrm{W} \cdot \mathrm{sec} / \mathrm{cm}^{2}$} \\
\hline \multirow{2}{*}{\multicolumn{5}{|c|}{$\begin{array}{l}{ }^{2} \text { Ozonization: } 1.0 \mathrm{mg} / \mathrm{l} \text { TROs for } 8.5 \mathrm{~min} \text { for Japanese flounder. } 0.5 \mathrm{mg} / \mathrm{l} \text { for } 5 \mathrm{~min} \text { for Barfin flounder. } \\
{ }^{3} \text { Electrolization: } 0.5 \mathrm{mg} / l \text { chlorine for } 5 \mathrm{~min} \text {. }\end{array}$}} \\
\hline & & & & \\
\hline \multicolumn{5}{|c|}{${ }^{4}$ Tank size: $0.5 \mathrm{t}$, Number of fish: 2000 , Duration: 49 days, Feeding: 1 time/day. } \\
\hline \multicolumn{5}{|c|}{${ }^{5}$ Tank size: $0.5 \mathrm{t}$, Number of fish: $6500-7100$, Duration: 30 days, Feeding: 2 times/day. } \\
\hline
\end{tabular}


cultured in UV irradiated, ozonized and electrolyzed seawater are shown in Table 5. No statistically significant differences in survival rates were found between the three groups of fish cultured with treated water.

Ozonized and electrolyzed seawater have been demonstrated to be effective for disinfecting equipment used in aquaculture ${ }^{15,16)}$ and ozonized seawater is effective for disinfecting fertilized barfin flounder eggs contaminated with viral nervous necrosis virus. $^{17)}$ Therefore, ozonization and electrolization of seawater seem to be effective methods for disinfection of the water for fish culture.

\section{CONCLUSION}

Gram negative bacteria and fish rhabdoviruses, herpesviruses and iridoviruses were killed when UV irradiated at the dose of $10^{4} \mu \mathrm{W} \cdot \mathrm{sec} / \mathrm{cm}^{2}$. Standard, inexpensive UV lamps can irradiate at that dosage and may be suitable for hatcheries or culturing stations that have problems caused by these microorganisms. This would be the best method for disinfection of UV susceptible pathogens. Water contaminated with Gram-positive bacteria, fish birnaviruses, fish reoviruses, fish nodaviruses and aquatic fungi that showed lower susceptibility should be disinfected with ozonization, electrolization or high quality UV lamps.

Disinfection of wastewater is necessary to prevent pathogenic contamination of the environments. Electrolization is easy to scale up and can be used to treat a large volume of water, thus making it a suitable method for disinfecting wastewater.

\section{ACKNOELEDGMENT}

This research was supported in part by Grant in Aid for Scientific research (B)(2) No.09556041 and (B)(2) 13556027 under the Ministry of Education, Science, Sports and Technology, Japan.

\section{REFERENCES}

1. Vlasenko M.I. Ultraviolet rays as a method for the control of diseases of fish eggs and young fishes. Problems of Ichthyol. 1969; 9: 697-705.

2. Hoffman G.L. Disinfection of contaminated water by ultraviolet irradiation, with emphasis on whirling disease (Myxosoma cerebralis) and its effect on fish. Trans. Amer. Fish. Soc. 1974; 3; 541-550.

3. Noormandeau D.A. Progress report, Project F-14-R-3, State of New Hampshire, 1968.

4. Kimura T, Yoshimizu M, Tajima K, Ezura Y, Sakai M.
Disinfection of hatchery water supply by ultraviolet (U.V.) irradiation- I . Susceptibility of some fish-pathogenic bacterium and microorganisms inhabiting pond waters. Nippon Suisan Gakkaishi 1976; 42: 207-211.

5. Kimura T, Yoshimizu M, Tajima K, Ezura Y. Disinfection of hatchery water supply by ultraviolet (U.V.) irradiationII. U.V. susceptibility of some fish pathogenic fungi. Fish patholo. 1980; 14: 133-137.

6. Yoshimizu M, Takizawa H, Kimura T. U.V. susceptibility of some fish pathogenic viruses. Fish pathol. 1986; 21: 47-52.

7. Yoshimizu $M$, Sami $M$, Kohara $M$, Yamazaki $T$ and Kimura T. Detection of IHNV in hatchery water by molecular filtration method and effectiveness of U.V. irradiation on IHNV infectivity. Nippon Suisan Gakkaishi 1991; 57: 555-560.

8. Kimura $T$, Yoshimizu $M$, Atoda $M$. Disinfection of hatchery water supply by ultraviolet (U.V.) irradiation-III. Effect of disinfection of hatchery water supply by ultraviolet irradiation on hatching rate of salmonid eggs. Fish pathol. 1980; 14: 139-142.

9. Yoshimizu M, Hyuga S, Oh M.-J., Ito S, Ezura Y. Disinfectant effect of oxidant produced by ozonization of sea water on fish pathogenic viruses, bacteria and ciliata. In "Diseases in Asian Aquaculture II", Asian Fisheries Society, Manilla, Phillipines 1995; pp. 203-209.

10. Itoh S, Yoshimizu M, Ezura Y. Disinfectant effects of low level of total residual oxidants in artificial seawater on fish pathogenic microorganisms. Nippon Suisan Gakkaishi 1997; 63: 97-102.

11. Itoh S, Yoshimizu M, Oh M.-J., Hyuuga S, Watanabe K, Hayakawa Y, Ezura Y. Effects of ozonized seawater on bacterial pollution and survival of cultured flounders (Paralichthys olivaceus and Verasper moseri). Suisanzoshoku 1996; 44: 457-463.

12. Kasai H, Watanabe K, Yoshimizu M. Disinfectant effects of hypochlorite produced by batch electrolytic system on fish pathogenic bacteria and virus. Suisanzoshoku 2001; 49: 237-241.

13. Kasai H, Ishikawa A, Hori Y, Watanabe K, Yoshimizu M. Disinfectant effects of electrolyzed salt water on fish pathogenic bacteria and viruses. Nippon Suisan Gakkaishi 2000; 66: 1020-1025.

14. Kasai H, Watanabe K, Yoshimizu M. Bactericidal effect of continuous flow electrolyzer on hatchery waste-seawater. Nippon Suisan Gakkaishi 2001; 67: 222-225.

15. Watanabe $\mathrm{K}$, Yoshimizu $\mathrm{M}$. Disinfection of equipments for aquaculture and fertilized eggs by ozonated seawater. Fish pathol. 1998; 33: 145-146.

16. Watanabe $K$, Yoshimizu $M$. Disinfection of equipment for aquaculture by electrolyzed seawater. Nippon Suisan Gakkaishi 2001; 67: 304-305.

17. Watanabe K, Yoshimizu M. Disinfection of viral nervous necrosis contaminated fertilized eggs by ozonated seawater. Nippon Suisan Gakkaishi 2000; 66: 1066-1067. 